\title{
ANALYSIS OF SURFACE WAVES RECORDED AT A MASS MOVEMENT IN BRASILIA, BRAZIL: AN IMPLICATION IN HAZARD MITIGATION
}

\author{
ANÁLISE DE ONDAS DE SUPERFÍCIE REGISTRADAS EM UM MOVIMENTO DE MASSAS EM \\ BRASÍLIA, BRASIL: UMA IMPLICAÇÃO NA MITIGAÇÃO DE RISCOS
}

\author{
Yawar HUSSAIN ${ }^{1}$; Hernan MARTINEZ-CARVAJAL ${ }^{2}$; Martín CÁRDENAS-SOTO³; \\ Rogério Elias Soares UAGODA ${ }^{4}$ \\ ${ }^{1}$ Department of Civil and Environmental Engineering, University of Brasília. Email: yawar.pgn@gmail.com \\ ${ }^{2}$ Faculty of Mines; National University of Columbia. Email: hmartinezc30@gmail.com \\ ${ }^{3}$ Engineering Faculty, National Autonomous University of Mexico. Email: martinc@unam.mx \\ ${ }^{4}$ Department of Geography, University of Brasilia. Email: rogeriouagoda@unb.br

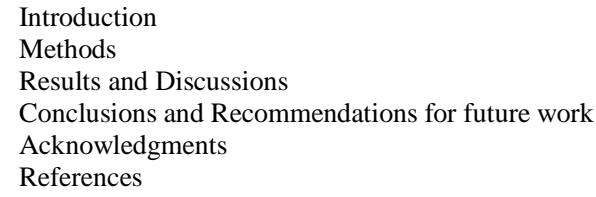

\begin{abstract}
Ever increasing urbanization over the thick and less cohesive soil of the Federal District (DF) - Brazil, has increased area's vulnerability to natural hazards, especially the soil erosion and mass movement. This preliminarily study applied noise based geophysical techniques like power spectral density (PSD), horizontal to vertical spectral ratio (HVSR), multichannel analysis of surface waves (MASW) and noise interferometry to a mass movement in Brasilia for the understating of geodynamic processes working in the background of these hazards. Here obtained results show a uniform stratigraphic peak at $2 \mathrm{~Hz}$ observed on all HVSR curves, a four layered shear wave section was obtained by MASW. Dispersion curve (frequency vs phase velocity) shows first and second fundamental modes at frequencies of 5 and $25 \mathrm{~Hz}$, respectively. Noise correlograms show time delay larger than $+-0.5 \mathrm{sec}$ on the waveforms of ZR (vertical-radial) component, mainly in acausal part. Relative velocity changes calculated by stretching technique show anomalous trends in response to rainfall events. Follow research will focus on the detection of possible changes in noise records within mass movement mainly related to natural triggering factors (rainfall and river erosion) under more controlled data conditions.
\end{abstract}

Palavras-chave: HVSR; MASW; SPD; Noise Interferometry; Empirical Green Function .

RESUMO - A crescente urbanização sobre o solo espesso e pouco coeso do Distrito Federal (DF) - Brasil, aumentou a vulnerabilidade da área aos riscos naturais, especialmente a erosão do solo e movimento de massa. Este estudo preliminar aplicou técnicas de geofísica baseadas em ruído, como a densidade espectral de potência (PSD), relação espectral horizontal a vertical (HVSR), análise multicanal de ondas de superfície (MASW) e interferometria de ruído para um movimento de massa em Brasília para a compreensão de processos geodinâmicos que atuam na ocorrência destes acidentes. Os resultados obtidos aqui mostram um pico estratigráfico uniforme a $2 \mathrm{~Hz}$ observado em todas as curvas de HVSR, uma seção de onda de cisalhamento em quatro camadas foi obtida por MASW. A curva de dispersão (freqüência vs velocidade de fase) mostra as primeria e segunda modas fundamentais em freqüências de 5 e $25 \mathrm{~Hz}$, respectivamente. Os correlogramas de ruído mostram atrasos de tempo maiores que + - 0,5 seg nas formas de onda da componente ZR (vertical-radial), principalmente na parte acausal. As mudanças de velocidade relativa calculadas pela técnica de alongamento mostram tendências anômalas em resposta a eventos pluviométricos. A sequência da pesquisa incidirá na deteç̧ão de possíveis mudanças nos registros de ruído no movimento de massa, principalmente relacionadas a fatores desencadeantes naturais (erosão de chuva e de rio) em condições de dados mais controladas.

Keywords: HVSR, MASW, SPD, Interferometria de ruído, Função empírica verde.

\section{INTRODUCTION}

The sallow rainfall triggered mass movements have a greater share in the global terrestrial hazards. The tragedies of 1967 in Rio de Janeiro are the tragic reminder of the atrocities caused by the shallow rainfall triggered landslide along with unplanned urban growths around the city (Coelho Netto et al., 2007; Gomes et al. 2016). Saprolitic soils of the region have variable geotechnical parameters depending on the type of parent rocks and degree of weathering. These soils also generally show highly saturated hydraulic conductivity values (Avelar \& Coelho Netto, 1992). Area of District Federal (DF) is characterized by the weak soil which is less supportive for civil engineering structures.
The growth of population in surrounding regions of DF has greatly affected the ecosystem of the area by distrusting the natural drainages that are not compensated with suitable managerial works. The water quality deterioration and soil erosion are two major environmental responses to these unplanned urban growths in DF (Mendonça et al., 1994).

In these scenarios, where geodynamic processes are at work in urban environments, passive geophysical techniques are favored because they can provide data at relatively lower costs without creating any disturbances in the environment.

Noise data has a potential of providing high spatiotemporal resolution informations required 
for the identification of these processes (Burtin et al., 2008). Noise are the ambient vibrations created by the action of the ocean, climatic variabilities and cultural activities on earth, each source of noise has its own frequency ranges and its energy change with time.

These ambient vibrations obey wave equations, are present everywhere and hence can be used for the understanding of signals generated in response to variabilities in landscape dynamics (Burtin et al., 2014). The energy of noise is variable in time. Taking these variabilities of noise under considerations a preliminary noise analysis is applied to a mass movement in Brasília, Brazil for the analysis of landscape dynamics (Hussain et al. 2017a).

Horizontal to Vertical Spectral Ratio (HVSR) curve (Nakamura, 1989) technique is strongly conditioned by the properties (depth and impedance contrast) of the interface between the soft sediment and the bedrock (Parolai et al., 2005) while it is poorly informative about the s- wave velocity of the sedimentary layers.

On the other hand the dispersion (frequency vs phase velocity) curves of array technique (MASW) constraints mainly the s-wave velocity structure of the subsurface soil (Park et al. 1999). In noise interferometry, a green function or impulse response of the medium between two sensors is obtained by crosscorrelation of the recorded noise. In this technique, one sensor acts as a virtual source. The Empirical Green Function (EGF) corresponds to impulse response if noise sources are uniformly distributed around the sensors (Planes et al., 2016).

In this preliminary study the famous techniques of site characterization like PSD, HVSR MASW and noise interferometry are applied. Finally, results obtained are briefly discussed and their relationship with seasonal rainfall induced stresses in mass movement buildup by the pore pressure, are recommended for the future detailed studies.

\section{METHODS}

DF has an area of $5,783 \mathrm{~km}^{2}$ and is located between $17^{0} 30^{\prime}$ and $16^{\circ} 03^{\prime}$ south and $47^{\circ} 25^{\prime}$ and $48^{\circ} 12^{\prime}$ west (Figure 1). Landforms of the area are under the effects of erosion due to rainfall. The climate in the area is semi-humid tropical with a rainy summer and dry winter. Average annual precipitation is $1500 \mathrm{~mm}$. Laminar soil loss at higher slopes is the problem. The technical studies to locate the new capital had indicated a high soil susceptibility to erosion (Mendonça et al., 1994). The slopes chosen for this work is located in the cow farm near a locality called 'Rua da Matto' as shown in Figure 1. There is intense limestone mining in the study area.

Three topossequences were drawn from the investigation of materials present in distinct slope morphologies (closed concavity, open concavity and convex-rectilinear slope). Results of geotechnical tests on the soil revealed low cohesion and friction angle in the valley area. The failure envelope curves showed high shear stress supported by the convex slope soils at the expense of others (Braga, 2015).

Data acquisition consists of deployment of 10 Sorcel L-4A-3D short period seismometers having natural a frequency response of $2 \mathrm{~Hz}$. Data was recorded in a continuous mode at sampling rate of 250 sample per second (SPS) with DASS130 Ref-Tek dataloggers. The time and positions are provided by the ten GPS-130 locks. Data was recorded between Julian day 306 to 324 year 2016. The sensors were placed in 2-Dimensional (2-D) geometry where average sensor spacing were kept less than 20 meters (Hussain et al., 2017b).

For MASW profile length of 44 meters constitute of 23 geophones of $14.5 \mathrm{~Hz}$ along with Geometric data recording system. We took 15 hammer $(8 \mathrm{~kg})$ strikes at each point and were stacked. The shots were taken at 5 meters away from the first geophone and same is repeated for the last geophone. One additional shot was taken at the center of the profile. The recording was done at the sample rate of 0.25 mili-sec with record length of 1 sec.

Processing steps consist of detrend of signal, mean subtraction, and then finally the instrument response was removed (Bensen et al., 2007). Then multitaper method (Thomson, 1982) was applied to a 1-hour time window and then power spectrum was estimated. In this way a high frequency resolution is achieved for shorter record, which decreases the number of computed frequencies in the spectrum.

Cross-correlations of all pair of stations (S1 to S8) for (ZZ), radial-radial (RR) and transverse-transverse (TT) were done to obtain the Empirical Green Functions (EGF). 
The cross-correlation was done at 4 s time window and stacked EGFs (900 time windows of $4 \mathrm{~s}$ ) for each hour. Stretching Technique (ST) is applied to the coda part of

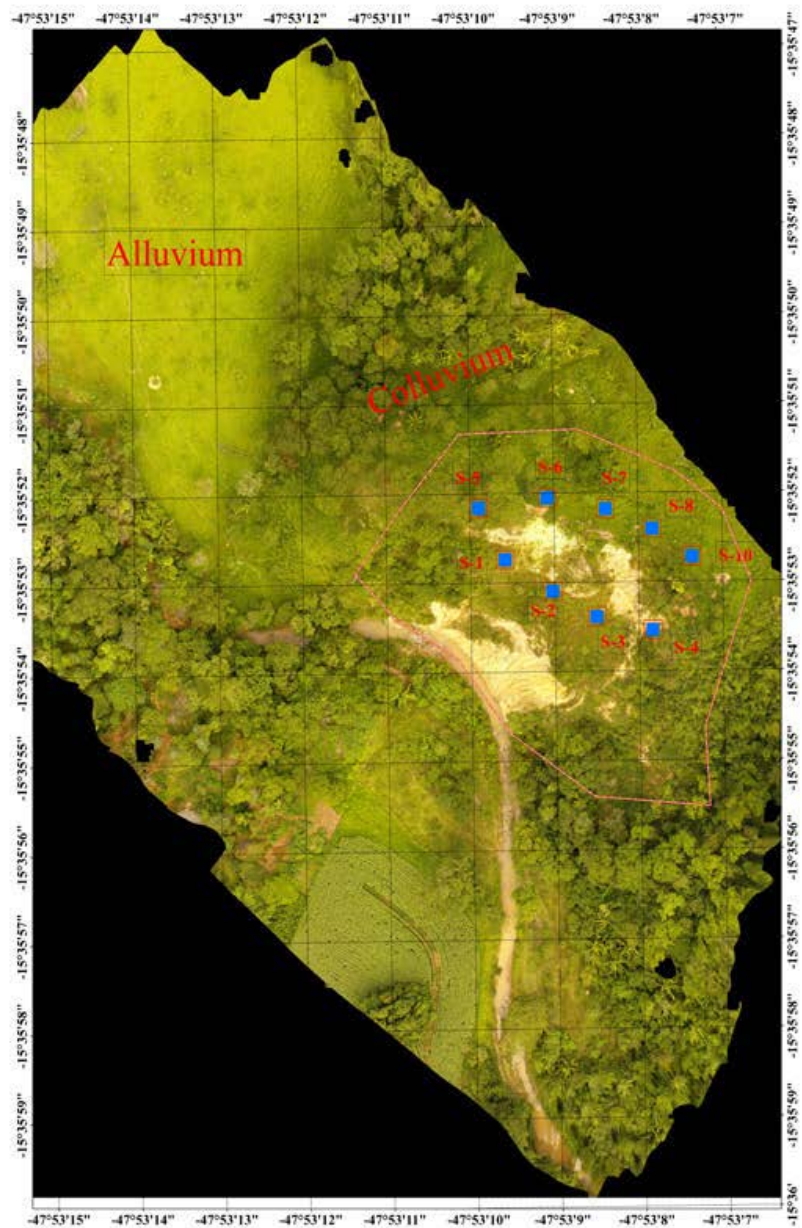

EGF (casual part, between 1 and 2 s). The reference trace was the stack of the 24 EGF and the analysis was done with filtered traces between 4 and $12 \mathrm{~Hz}$.

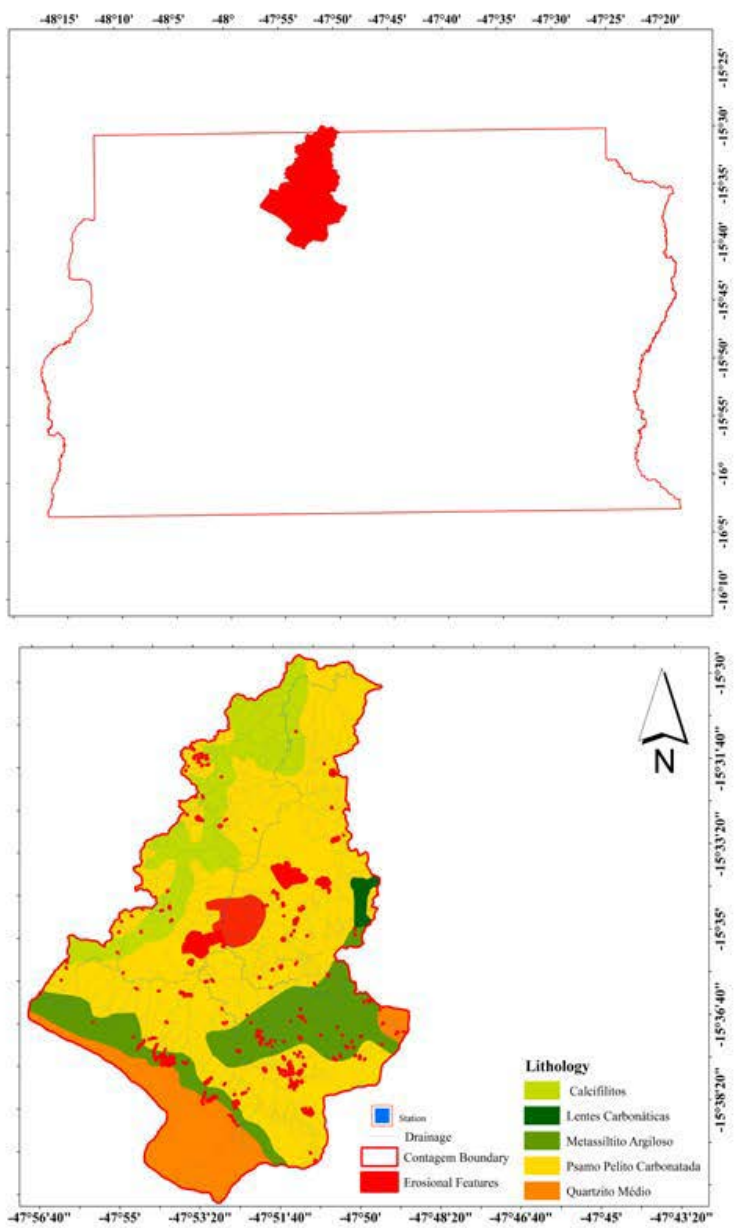

Figure 1 - Location of the Ribeirão Contagem Basin on map of Brasilia (right top), boundary of Contagem River basin with lithological units (bottom right) and mass movement along with the positions of stations (left).

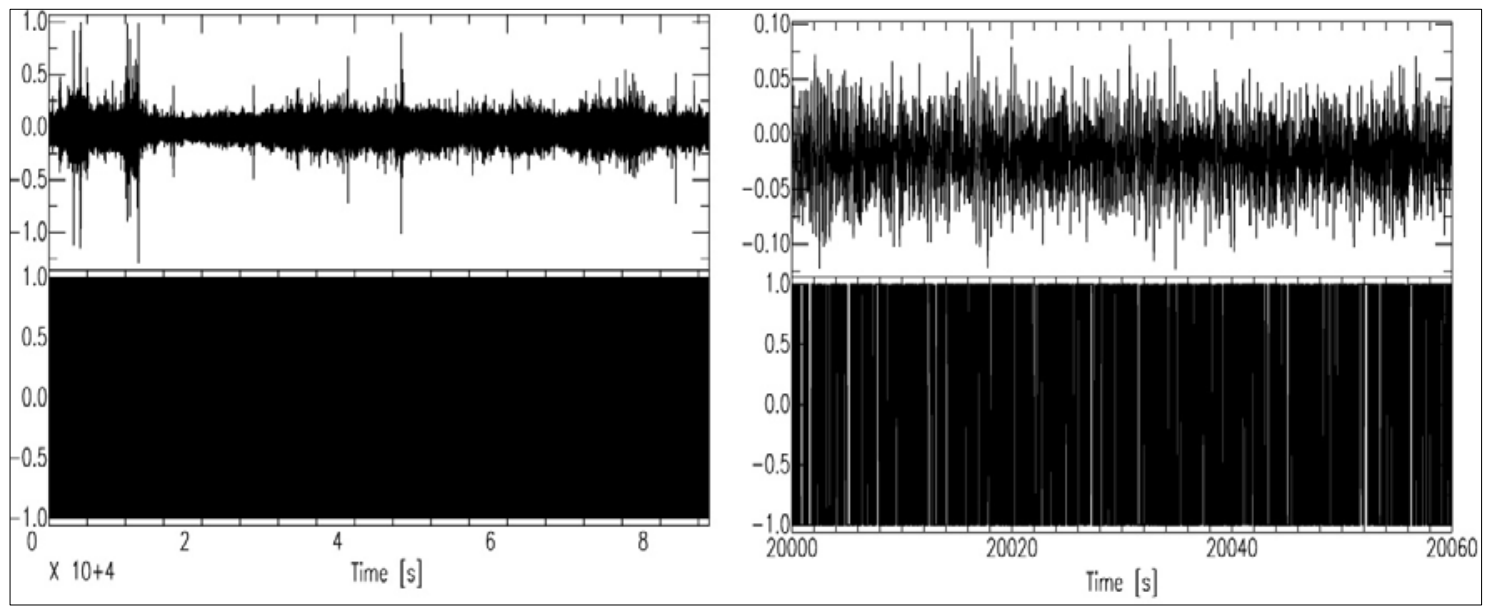

Figure 2 - One hour record of ambient noise (left). Unprocessed trace is displayed after normalization. A segment of 30 sec around a transient event (right). Units in the figure are arbitrary.

\section{RESULTS AND DISCUSSIONS}

To study the variability of the seismic noise with time, we plot the PSD levels as a function of versus time in one day long spectrograms.
The spectrograms enhance several interesting patterns with different characteristics. Here obtained results output that the contribution to 
the noise recorded at stations inside and outside the monitored mass movement are likely due to several factors including man-induced disturbance and instrument self-noise. It can be seen from Figure 3 that energy of recoded noise is lower at frequency of $2 \mathrm{~Hz}$ mainly because of the limitations of the sensors $(2 \mathrm{~Hz})$ used for the recoding. However, the energy is higher above $8 \mathrm{~Hz}$. Between 4 to $8 \mathrm{~Hz}$ there is change in energy levels of the recording mainly because of cultural activities near the station like village, road traffic, mining and cow farm etc.

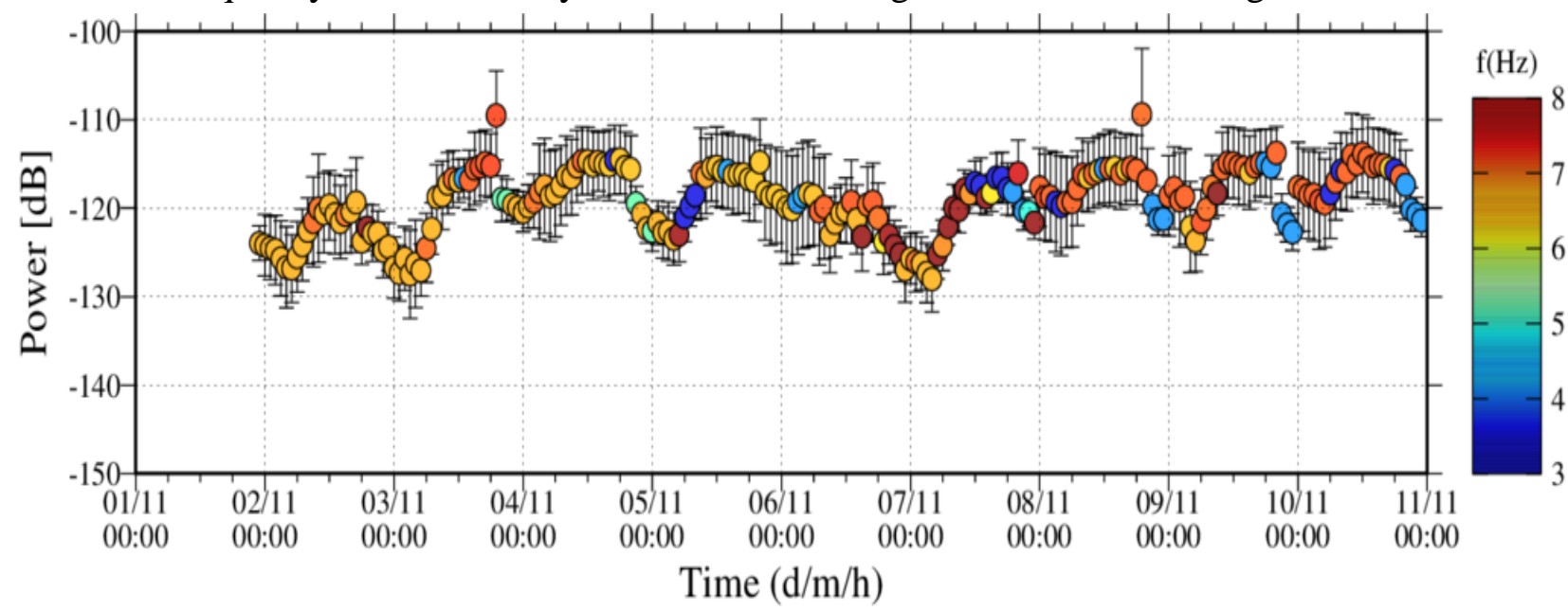

Figure 3 - SPD at vertical component of S6 station lie outside the mass movement. Each circle represents the average value between 3 and $8 \mathrm{~Hz}$ of the SPD. The scale bar indicates the frequency range where the SPD are averaged while scale bars are average mean error (Hussain et al. 2017).

HVSR variability in the area is related to the topographic signature of the bedrock. All curves show a uniform peak at $2 \mathrm{~Hz}$ that corresponds to the depth of carbonate rocks along with this stratigraphic peak there are also small peak that can be linked to landslide dynamic (Figure 4). Horizontal to vertical spectral ratio of the three component records at each point was done with Geopsy software. Future detailed studies are required to test this hypothesis.

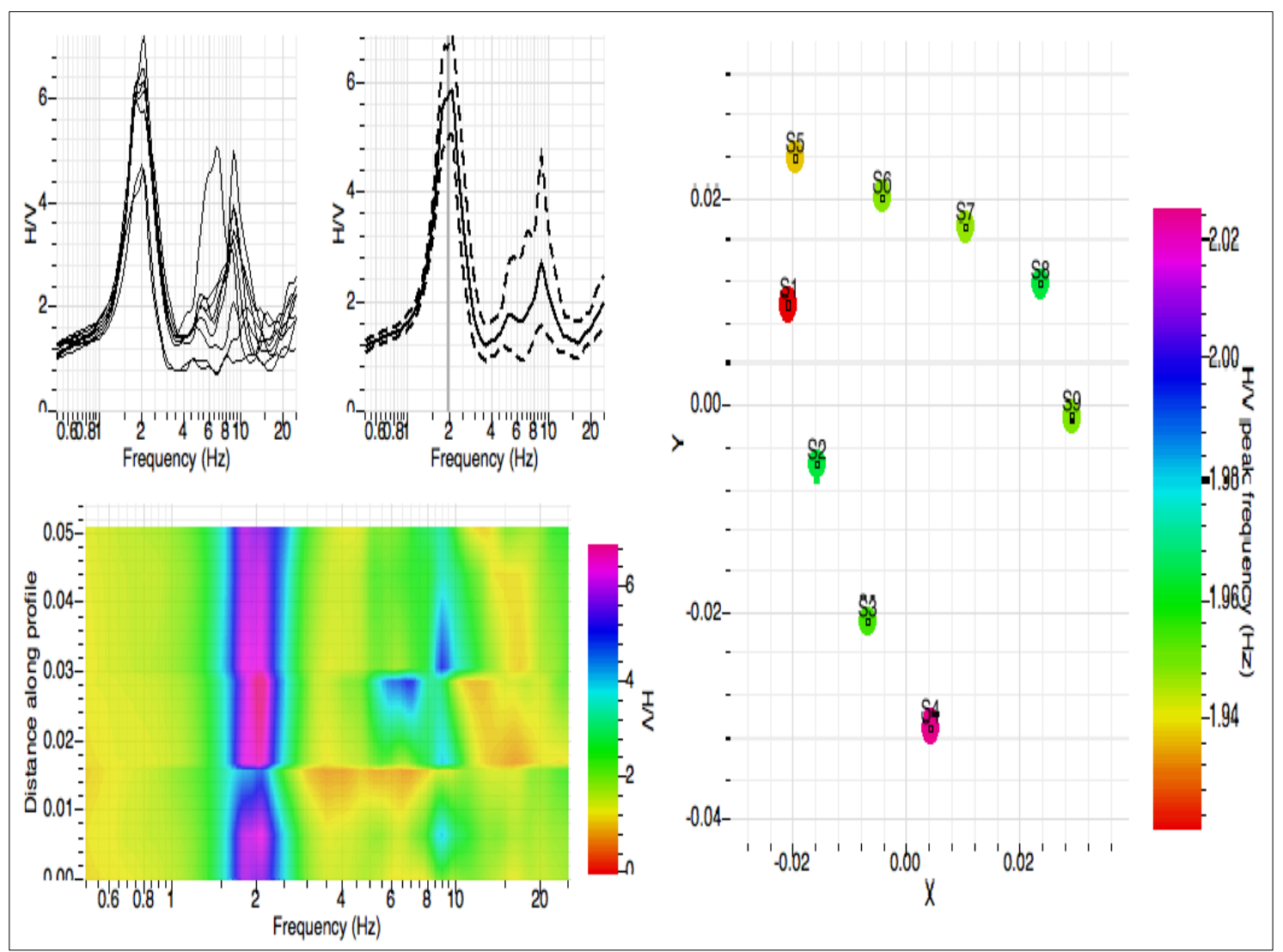

Figure 4 - HVSR curves (top left) and variation of fundamental frequency along sensor array (bottom left). Spatial variability of fundamental frequency (right). 
Shear wave velocity of layers are 400, 590, 710, $690 \mathrm{~m} / \mathrm{s}$. This depth dependent variability of shear wave velocity is keep on increasing with depth that show the increase in rigidity. The observed $\mathrm{Vp}$ velocities are, 500, 1000 and $1500 \mathrm{~m} / \mathrm{s}$. For MASW it is not possible to penetrate more than $20 \mathrm{~m}$ due to the a quarter length wave limitation (Figure 5).

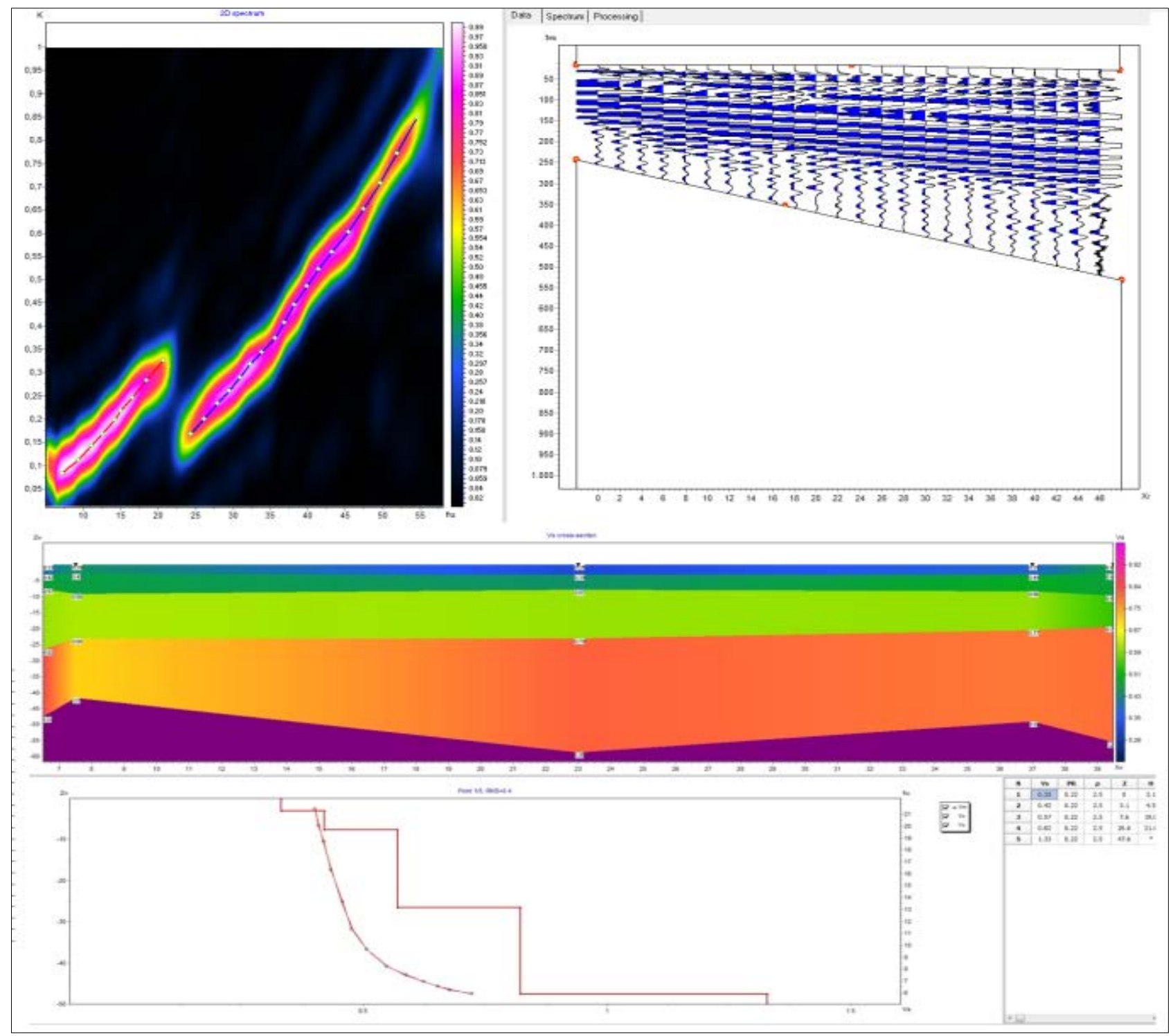

Figure 5 - Dispersion curve (top left), refraction shots gathers (top right), and velocity depth profile (bottom).

Figure 6 shows the cross-correlation functions between S1 and S8 station for ZZ, RR and ZR components.

We observe that $\mathrm{ZZ}$ and $\mathrm{RR}$ traces are almost identical, the correlation pulse is close to zero, indicating the proximity of the stations. Same results are observed on TT component. However, ZR component exhibits waveforms in times delays larger than $+-0.5 \mathrm{~s}$, mainly in acausal part.

Some of these arrivals could be ballistic waves, but in general, coda waves trains appear and disappear along the day. This result is consistent with PSD analysis, indicating changes in the subsoil structure are due to surrounding noise sources.

Symmetrical results in EGF indicate that we can recover the Green function completely, but it is impossible.

Relative velocity changes between station S5 and S6 from midnight of day 07/11/2016 to midnight of next day high velocity changes are seen that are mainly because of an intense rainfall event (Figure 7).

In future, the relative velocity changes $\mathrm{dv} / \mathrm{v}$ among all the possible station pairs will be done by considering all three temporal scales (seasons) i.e. before, during and after the rainy season in Brasília, Brazil. 


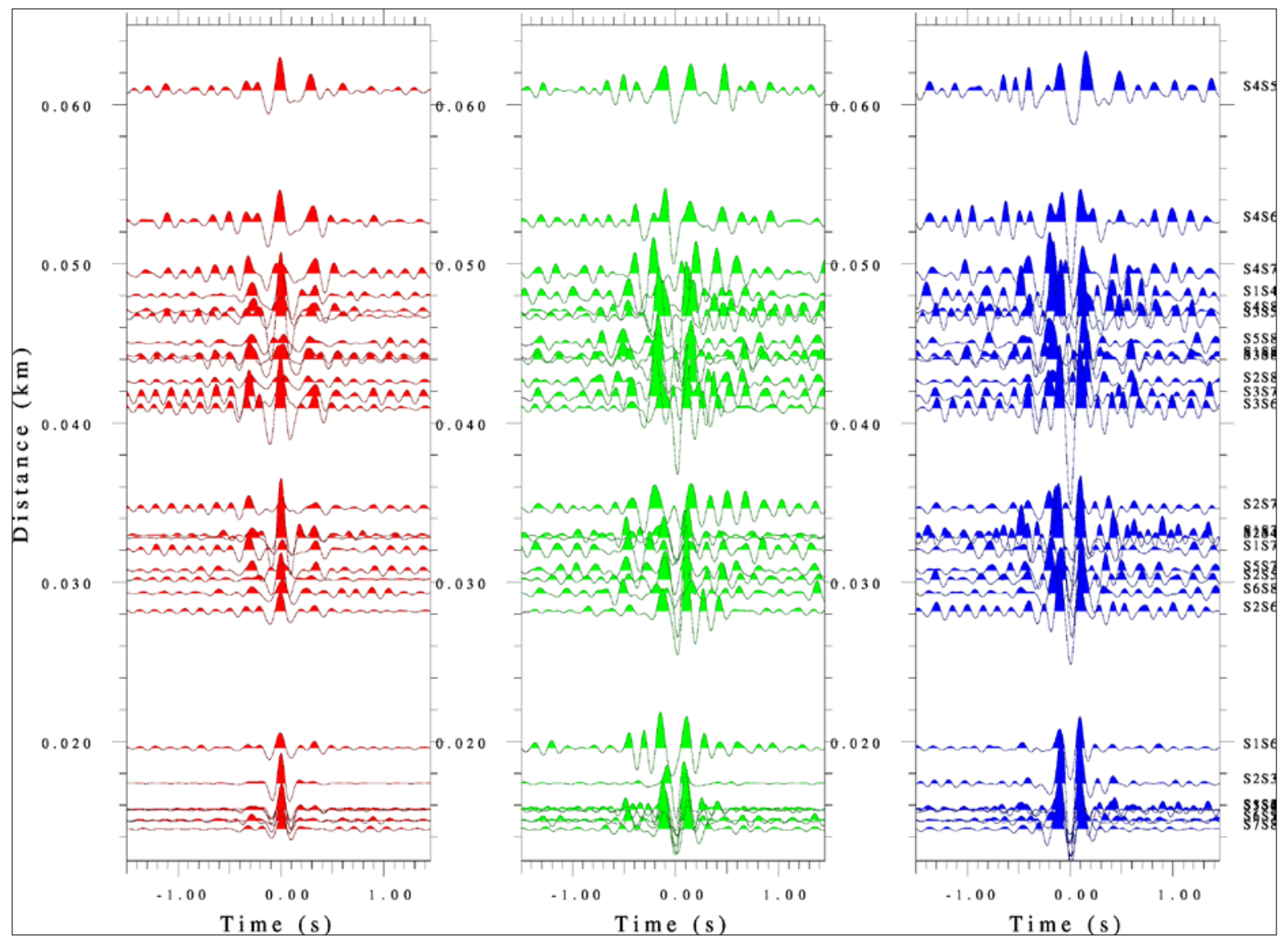

Figure 6 - Cross correlations functions; ZZ, RR and ZR components bandpass filtered between 3 to 8 Hz. One day long cross-correlation calculated for dry period record (November 2, 2016).

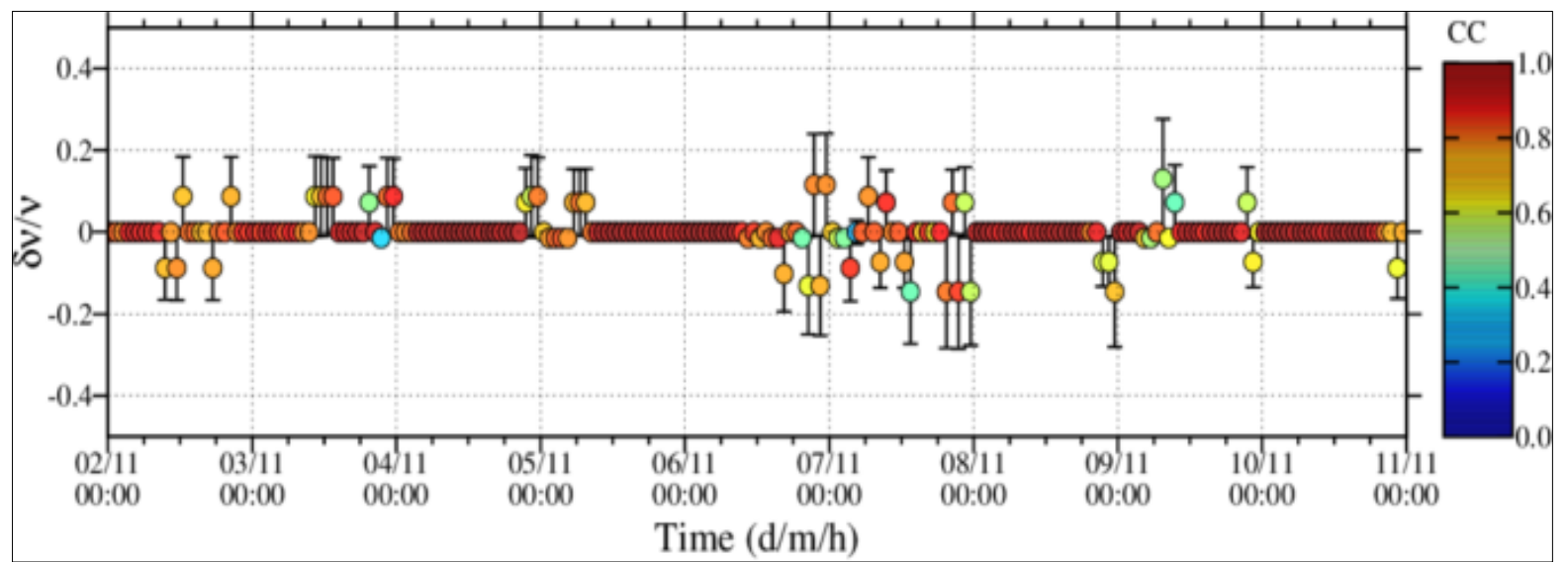

Figure 7 - Relative velocity change dv/v between S5 and S6 for ZZ component. The color bar presents CC and scale bars are mean error.

\section{CONCLUSIONS AND RECOMMENDATIONS FOR FUTURE WORK}

The present study is a preliminarily step that will lead to a comprehensive application of geophysical techniques for hazard assessment. Following conclusions are drawn form the analysis. Spectral analysis showed a day-night variability of noise energy over $3-8 \mathrm{~Hz}$ frequency range. There is a peak on HVSR curves at $2 \mathrm{~Hz}$ which is uniform on all the stations both inside and outside the mass movement. Noise sources are uniformly distributed. Relative change $(\mathrm{dv} / \mathrm{v})$ in surface wave velocities showed an anomalous response to rainfall episodes.

However, there are several technical and practical issues that deserve further investigation. This study only begins to reveal the noise characteristics. Some unanswered questions have been exposed in this endeavor such as the connection between noise changes and water related stresses in the mass 
movement. Future analyses will be focused on highlighting noise properties changes to be related to variation of physical properties mass movement (i.e. due to soil saturation after rainfalls, or river based stresses).

Further detailed studies are required for the understanding of dynamism involved in the triggering of that mass movement. The recommended studies are Nanoseismic Monitoring (Joswig, 2008), Time-lapse resistivity and time-lapse noise interferometer (Snieder, 2004; Curtis, et al. 2006) more detailed and dense HVSR (Nakamura, 1989) measurements in and around the mass movement as well as considering more detailed day-night variabilities. For better shear velocity measurement more MASW profiles are required with same seismometers $(2 \mathrm{~Hz})$ so that a joint inversion of HVSR curves and MASW can be done. Alone with these studies strong data controlled will be acquired with soil moisture sensors, tensiometers, pluviometers and rainguages are required for the accurate measurement of the possible triggering factors.

\section{ACKNOWLEDGMENTS}

The present study is financially supported by research project "Análise das Dinâmicas de uma Encosta Artificial Instável Usando um Monitoramento Nanosismico e Simulação Numérica". This research was partially supported by UNAM-DGAPA PAPIIT IN117217 project. The seismometers used in this study were taken from Pool of Brazilian Equipments (PegBr), Rio de Janeiro.

\section{REFERENCES}

AVELAR, A.S. \& COELHO NETTO, A.L. "Fluxos d'água subsuperficiais associados a origem das formas côncavas do relevo". In: CONFERÊNCIA BRASILEIRA SOBRE ESTABILIDADE DE ENCOSTAS, I, 1992, Piracicaba. Anais...Piracicaba: 1992, v. 2, p. 709-720,

BRAGA, L.M. Análise geomorfologica e geotécnica em encostas suscetíveis a processos erosivos - bacia hidrográfica do ribeirão contagem- DF. Brasília, 2015. 67p. Masters Desertation (in Purtguese) - Department of Civil and Enviromental Engineering, University of Brasília, Brazil. BENSEN, G.D.; RITZWOLLER, M.H.; BARMIN, M.P.; LEVSHIN, A.L.; LIN, F.; MOSCHETTI, M.P. SHAPIRO, N.M.; YANG, Y. Processing seismic ambient noise data to obtain reliable broad-band surface wave dispersion measurements. Geophysical Journal International, v. 169, n. 3, p. 1239-1260, 2007.

BURTIN, A.; BOLLINGER, L.; VERGNE, J., CATTIN, R.; NÁBĚLEK, J.L. Spectral analysis of seismic noise induced by rivers: a new tool to monitor spatiotemporal changes in stream hydrodynamics. Journal of Geophysical Research, v. 113, 2008.

BURTIN, A.; HOVIUS, N.; MCARDELL, B.W.; TUROWSKI, J.M.; VERGNE, J. Seismic constraints on dynamic links between geomorphic processes and routing of sediment in a steep mountain catchment. Earth Surface Dynamics, v. 2, n. 1 , p. 21,2014

COELHO NETTO, A.L.; AVELAR, A.S.; FERNANDES, M.C.; LACERDA, W.A. Landslide susceptibility in a mountainous geoecosystem, Tijuca Massif, Rio de Janeiro: The role of morphometric subdivision of the terrain. Geomorphology, v. 87, p. 120-131, 2007.

CURTIS, A.; GERSTOFT, P.; SATO, H.; SNIEDER, R.; WAPENAAR, K. Seismic interferometry - turning noise into signal. The Leading Edge, v. 25, p. 1082-1092, 2006.

GOMES, R.A.T.; GUIMARÃES, R.F.; DE CARVALHO, J.; ABÍLIO, O.; FERNANDES, N.F.; DO AMARAL JÚNIOR, E.V. Combining spatial models for shallow landslides and debris-flows prediction. Remote Sensing, v. 5, n. 5, p. 22192237, 2013.

HUSSAIN, Y., MARTINEZ-CARVAJAL, H., CÁRDENASSOTO, M., UAGODA, R., MARTINO, S. \& HUSSAIN, B.M. Microtremor response of a mass movement in federal district of Brazil. Anuário do Instituto de Geociências UFRJ, v. 40, n.3, p. 212-221, 2017a.

HUSSAIN, Y.; CÁRDENAS-SOTO, M.; MARTINEZCARAJAL, H.; UAGODA, R.; SOARES, J.; MARTINO, S. Spectral Analysis of the Recorded Ambient Vibration at a Mass Movement in Brasilia. In: SYMPOSIUM ON THE APPLICATION OF GEOPHYSICS TO ENGINEERING AND ENVIRONMENTAL PROBLEMS, 2017b, Denver. Proceeding... Denver: Society of Exploration Geophysicists and Environment and Engineering Geophysical Society, 2017, p. 214-218.

JOSWIG, M. Nanoseismic monitoring fills the gap between microseismic networks and passive seismic. First Break, v. 26, n. 6, p.117-124, 2008.

MENDONÇA, A.F.; PIRES, A.C.B.; BARROS, J.G.C. Pseudosinkhole occurrences in Brasilia, Brazil. Environmental Geology, v. 23, n. 1, p. 36-40, 1994.

NAKAMURA, Y. "A Method for Dynamic Characteristics Estimation of Subsurface using Microtremor on the Ground Surface”, Quarterly Report of Railway Technical Research Institute (RTRI), v. 30, n. 1, 1989.

PARK, C.B.; MILLER, R.D.; XIA, J. Multichannel analysis of surface waves. Geophysics, v. 64, n. 3, p. 800-808, 1999.

PAROLAI, S.; PICOZZI, M.; RICHWALSKI, S.M.; MILKEREIT, C. Joint inversion of phase velocity dispersion and $\mathrm{H} / \mathrm{V}$ ratio curves from seismic noise recordings using a genetic algorithm, considering higher modes. Geophysical Research Letters, v. 32, n. 1, 2005.

PLANES, T.; MOONEY, M.A.; RITTGERS, J.B.; PAREKH, M.L.; BEHM, M.; SNIEDER, R. Time-lapse monitoring of internal erosion in earthen dams and levees using ambient seismic noise. Géotechnique, v. 66, n. 4, p. 301-312, 2016.

SNIEDER, R. Extracting the Green's function from the correlation of coda waves: A derivation based on stationary phase. Golden: The Americal Physical Society, v. 69, 2004.

THOMSON, D.J. Spectrum estimation and harmonic analysis. Proceedings of the IEEE, v. 70, n. 9, p. 1055-1096, 1982.

Submetido em 14 de julho de 2017 Aceito em 18 de janeiro de 2018 